Historic, archived document

Do not assume content reflects current scientific knowledge, policies, or practices. 



\section{LIST OF PEONIES}

Offered for sale by H. W. Groschner, Napoleon, Ohio. All varieties guaranteed absolutely true to name.

\begin{tabular}{|c|c|c|c|c|}
\hline Avalanche & One $\mathrm{E}$ & $\begin{array}{l}\text { Eye Div. } \\
\$ .75\end{array}$ & $\begin{array}{c}\text { Strong } \\
\text { Div. } \\
\$ 1.00\end{array}$ & $\begin{array}{c}\text { One } \\
\text { Yr. } \\
\$ 1.25\end{array}$ \\
\hline Admiral Togo & & 1.00 & 1.25 & 1.50 \\
\hline Alice D. Joulvecourt & & .75 & 1.00 & 1.25 \\
\hline Alsace Lorraine .... & $\$ 2.00$ & 3.00 & 4.00 & 6.00 \\
\hline Albert Crousse . & & .75 & 1.00 & 1.50 \\
\hline Baroness Schroeder & & .75 & 1.00 & 1.25 \\
\hline Couronne D'Orr ..... & & .75 & 1.00 & 1.25 \\
\hline Claire Duboise & & .75 & 1.00 & 1.25 \\
\hline Coronation ... & & 1.00 & 1.50 & \\
\hline Duchess D'Nemours . & & .75 & 1.00 & 1.25 \\
\hline Delachii ............ & & .75 & $1: 00$ & 1.25 \\
\hline David (Kelway) & 2.50 & 3.00 & 5.00 & 7.00 \\
\hline Edulis Superba & & .75 & 1.00 & 1.25 \\
\hline Elwood Please ..... & & 1.00 & 1.50 & 2.00 \\
\hline Eugene Bigot & & .75 & 1.00 & 1.50 \\
\hline Eugenia Verdier .. & & .75 & 1.00 & 1.25 \\
\hline Festiva Maxima & & .75 & 1.00 & 1.25 \\
\hline Festiva $\ldots \ldots \ldots \ldots \ldots \ldots \ldots \ldots \ldots$ & & .75 & 1.00 & 1.25 \\
\hline Felix Crousee $\ldots \ldots \ldots \ldots \ldots \ldots \ldots$ & & .75 & 1.00 & 1.50 \\
\hline ...... & 3.00 & 4.00 & 5.00 & 8.00 \\
\hline ...... & & 1.00 & 1.50 & 2.00 \\
\hline Glo & 10.00 & 15.00 & 20.00 & 30.00 \\
\hline Cleveland & & 1.00 & 1.25 & 1.50 \\
\hline Gloire D' Chas. Gumbault ............. & & 1.00 & 1.25 & 1.50 \\
\hline$\ldots \ldots \ldots \ldots \ldots \ldots \ldots$ & & .75 & 1.00 & 1.25 \\
\hline ichau & 2.50 & 3.50 & 6.00 & 8.00 \\
\hline Kar & & 1.00 & 1.50 & 1.75 \\
\hline Lady Alexandra Dưfî & 2.50 & 3.50 & 7.00 & 9.00 \\
\hline Liv & & .75 & 1.00 & 1.50 \\
\hline$\ldots \ldots$ & & .75 & 1.00 & 1.50 \\
\hline La & 2.50 & 3.50 & 5.00 & 8.00 \\
\hline La & & .75 & 1.00 & 1.50 \\
\hline Laus & 4.00 & 5.00 & 7.50 & 10.00 \\
\hline Le & 8.00 & 10.00 & 18.00 & \\
\hline Lovlin & 3.00 & 4.00 & 6.00 & \\
\hline Lord Kitchener .... & & 1.00 & 1.50 & 2.00 \\
\hline Marie Crousse ... & & 1.25 & 1.75 & 2.50 \\
\hline n & & .75 & 1.00 & 1.25 \\
\hline Mons Dupo & & .75 & 1.00 & 1.50 \\
\hline Nions Jul & & 1.00 & 1.5 & 1.75 \\
\hline Dessert $\ldots$. & & 1.00 & 1.5 & 2.00 \\
\hline huzac .... & & 2.50 & 3.5 & 5.00 \\
\hline Ma & 3.50 & 5.00 & 7.50 & 12.00 \\
\hline sert & 2.50 & 3.50 & 6.00 & 8.00 \\
\hline $\mathrm{Mm}$ & & .75 & $1 .($ & 1.50 \\
\hline $\mathrm{Ma}$ & 3.00 & 4.50 & 7.50 & 9.00 \\
\hline Phyllis Kelway ... & 4.00 & 6.00 & 10.00 & 15.00 \\
\hline Phil & 10.00 & 12.00 & 20.00 & 28.00 \\
\hline Phi & & .75 & 11.00 & 1.25 \\
\hline ?2a & 3.5 & 5.00 & 9.00 & 12.00 \\
\hline Sol: & 2.50 & 3.50 & 7.50 & 10.00 \\
\hline Sple & & 1.50 & 2.00 & \\
\hline Sar & 3.50 & 4.50 & 8.00 & \\
\hline The & 2.50 & 3.50 & 6.00 & \\
\hline Tou & 1.50 & 3.00 & 5.0 & 7.50 \\
\hline e Guest & & 1.00 & 1.50 & 2.00 \\
\hline Pride of Esse & 3.50 & 5.00 & 9.00 & 15.00 \\
\hline Officinallis Rubr & & 1.00 & 1.25 & 1.75 \\
\hline llis $\operatorname{Ros}$ & . & 3.00 & -4.00 & 6.00 \\
\hline Des & & 1.00 & 1.50 & 2.00 \\
\hline
\end{tabular}

BRAND PEONIES

\begin{tabular}{|c|c|c|c|c|}
\hline manda Yale & & .75 & 1.00 & \\
\hline Chas. IfcKellip & 2.50 & 3.50 & 5.00 & \\
\hline Chestine Gowdy .. & 2.00 & 3.00 & 4.50 & \\
\hline Com. Emage & & .50 & .75 & 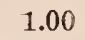 \\
\hline Fanny Crosby & & 1.00 & 1.50 & \\
\hline Henry Avery & 1.00 & 2.00 & 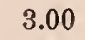 & \\
\hline Richard Carvel & 2.50 & 3.00 & 4.50 & \\
\hline Lora Dexheimer & 1.50 & 2.50 & 4.6. & \\
\hline fellow... . & 3.00 & 4.6 & 6.00 & \\
\hline lloch & 5.00 & 7.50 & 12.00 & \\
\hline & 3.00 & 4.00 & 6.00 & \\
\hline Winnei & 2.50 & 3.50 & 4.50 & \\
\hline
\end{tabular}

SINGLE PEONIES

Albifllora Carnea

Anamola Smouthi

Black Prince

Stanley

Defiance ....

L'Etincelante ....

Rosy Dawn (Barr)

Princess Matilde

Pride o

\section{JAPANESE PEONIES}

Alma

Attractio

$\begin{array}{lll}1.00 & 2.50 & 3.00\end{array}$

Ama-no-so

4.00

King of Engl

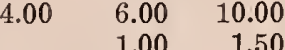

$\begin{array}{llll} & 1.00 & 1.50 & 2.00\end{array}$

King of England

Le Jour

$\begin{array}{lll}1.00 \quad & 1.00 & 1.50\end{array}$

Esther (Terry)

Gipsy 

leason that some one eye divisions have made a showing against larger roots, is that some of the larger sizes had too many eyes an were not sound and healthy. If the precaution is taken to remove half the eyes of strong divisions and one or two year roots that are badly affected with decay, are divided and some of the eyes remove from these divisions, the superiority of larger size Peony roots wil be proven. It stands to reason, to anyone with an open mind and not obsessed by greed and avarice, that a stronger root having more strength will give better results than a smaller one. Take my word for it, that a larger Peony root of new growth that is sound and healthy is far superior to one eye divisions. Because so many large size roots have been sent out in late years that were badly affected with disease, is not the fault of the size, but the grower who has so much business that he either does not care, or has not the time to give his business the personal and intelligent attention it should have. My advice is to invest in larger roots of fewer varieties of unquestioned and known quality, then to stretch the investment to include more sorts that are of doubtful quality and value. On account of the money saved, and exception could be made for the most expensive sorts, such as Glorious, Martha Bulloch, Philip Revoir, LeCygne, Ama-no-sode and others, that are worth the price charged for them but even with these I would advise nothing smaller than divisions. Take my word for it, that the varieties mentioned are treasures.

$$
\text { EXPLANATORY-EYES }
$$

The number of eves a Peony root has, is no criterion of its worth. Any intelligent Peony grower will agree with me that a soun root with few eyes is superior to a weak one with many. It is my practice when replanting, to remove all but one or two eyes from divisions and small divisions. I learned by experience that it pays to prune nursery stock, and also learned by experience, that it pays to remove some of the eyes from Peony roots.

My one eye divisions are as large as any grower sends out. I do not cut this size to order; most of them are small, independent root that have made an effort to strike out for themselves. There are only a limited number for sale every rear, and after these are sold, no more are available.

\section{DIVISIONS}

This is the standard commercial size sold by all growers. This grade is larger than one eye divisions and usually has two or thre eyes.

\section{STRONG DIVISIONS}

This is a larger size than the above and has more eyes.

$$
\text { ONE YEAR PLANTS }
$$

This size is a strong divisions that has been grown one year, so a year is gained. Most of the moderate priced sorts of this size will give a bloom and in the cheaper sorts more bloom, the roots of the more moderate and cheaper varieties will stand dividing without butchering the plant.

$$
\begin{array}{r}
\text { TWO YEAR PLANTS } \\
\text { My two year plants are not pitted with dect }
\end{array}
$$

作 will be saved in planting my two year Peonies. Price upon application.

$$
\text { NOTICE }
$$

I do not guarantee the number of eyes the larger sizes will have, some very fine sorts do not have many eyes, if eyes are wanter? you can be accommodated. There are an increasing number of persons every year who believe that I understand by business and request me to prepare their roots just like I would for myself and remove as many eyes as necessary for future best results.

$$
\text { Albiflora Carnea. }
$$

Albiflora Cannea. This is the wild Peony that grows wild on the plains of Siberia and is the parent of all the modern Chinese Peonies. the fir Peony to bloom and the color is a most beautiful light it the first Peony to bloom and the color is a most beautiful light pink. to be per bloom for this sort to A to be in bloom for Memorial Day. A

The nearest approach to a scarlet of any wers are large, of good substance end the plant 2 strong grower

Smouthii. The first Peony in $\mathrm{my}$ collection to bloom, flower bright red, foliage is lacinated like the leaves of delphiniums. Unlike Tenefolia, the flowers of this al stays green all sumer.

Phyllis Kelway. An extra choice pink Peony that should score above 90

Phillip Revoir is worth all the praise it has received. Blooms young, is a free and reliable bloomer and its fragrance so sweet that you can taste it.

David (Kelway.) Coral pink, a new distinct color in Peonies that will be much sought after.

Officinallis Rosea Superba. The true variety has one of the most beautiful shades of pink to be found in Peonies, and coming in time for Memorial Day, gives it added value. No grower has any considerable stock for sale, and I have only a few roots,

Suzanne Dessert. One of the darker pinks that is a beauty, strong grower and free bloomer.

Should be in all collections. I have given these beautiful forms special study and offer for sale varieties as fine as money will bur. The most of the sorts in my list are the last word of their color and

Pride of Langport. Bright peach pink, exquisite, blooms young. L'Eticelante. One of the finest darker pinks, extra fine.
Black Prince. (Thurlow.) A shade of dark red that is disBlack Prince. (Thurlow.) A shade of dark red that is di inct from all others.

Rosy Dawn. A fine, white flushed pink.

JAPS
Esther. As fine as any of the higher priced pink Japs and very distinct

Mikado. No finer red Jap.

Petite Renee. A medium pink Jap that is a beauty.

The Moore. A fine low priced dark red Jap.

Tome varieties are in very limited

sold out.

very limited supply and will soon be

\section{CARRIAGE}

One eye divisions and divisions of the expensive varieties, $15 \mathrm{c}$ $h$, 25c to Canada and long distance.

Divisions of moderate priced sorts 20c. To Canada and long distances, $25 \mathrm{c}$.

Strong divisions of cheaper sorts, 25c. Long distance and Canada, 30c.

One year, moderate and cheaper sorts, 35c; to Canada and long distance, $50 \mathrm{c}$.

When more than one plant is ordered, it is best to have them shipped by express.

Safe arrival guaranteed if shipment is insured, which must be aid by purchaser. Insurance is $5 \mathrm{c}$, up to $\$ 25.00$.

Address all orders to $H$. W. GROSCHNER, Napoleon, Ohio. All goods

All goods cash with order, except people who are known to me. 